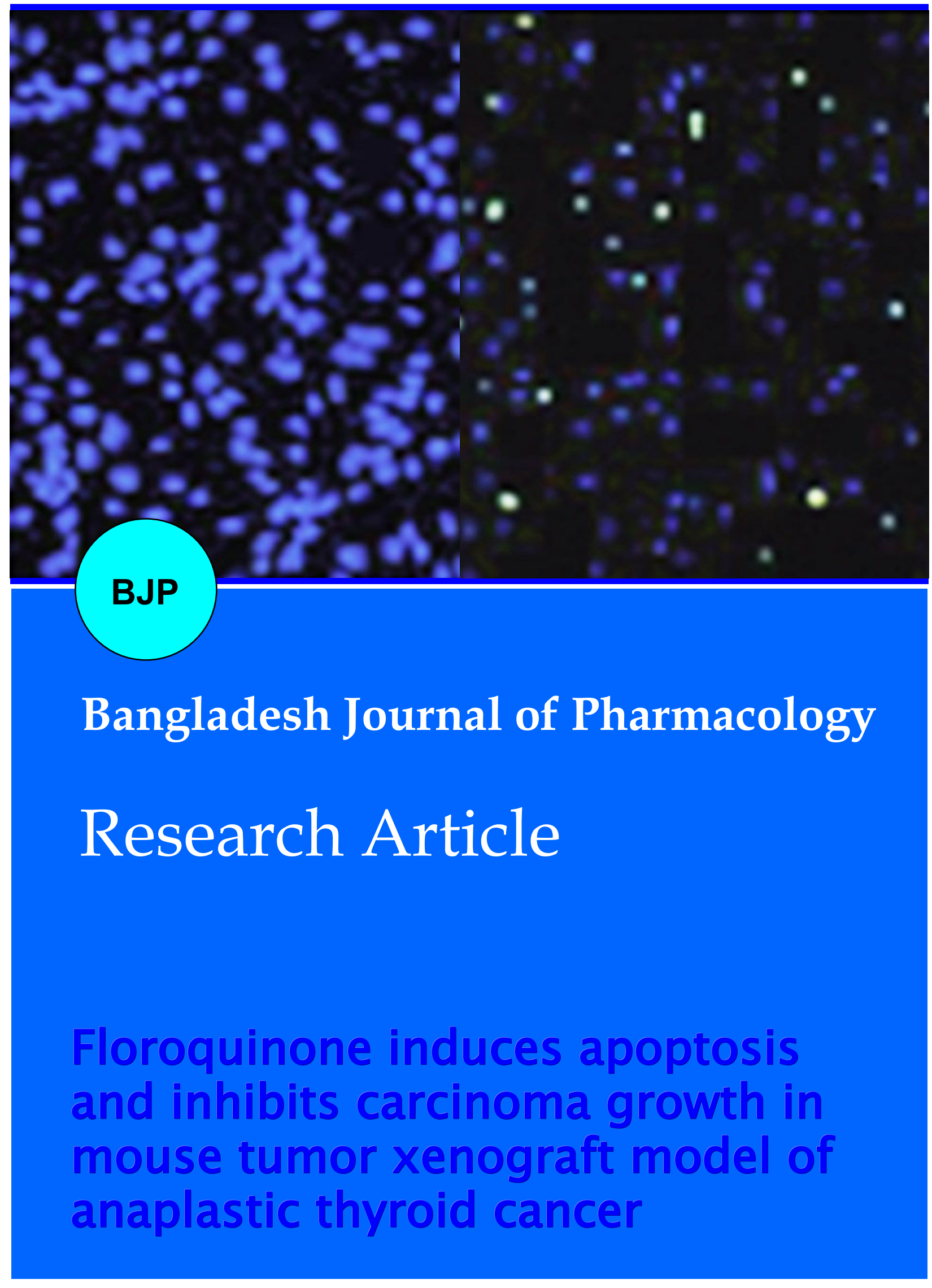




\title{
Floroquinone induces apoptosis and inhibits carcinoma growth in mouse tumor xenograft model of anaplastic thyroid cancer
}

\author{
Li-Na Zhao', Li-Bo Chen², Xiu-Hua Hao', Zhang Hu', Jing Zhang1 and Chun-Hai Zhang1 \\ ${ }^{1}$ Department of Thyroid Surgery, China-Japan Union Hospital of Jilin University, Changchun, Jilin 130-033, China; \\ ${ }^{2}$ Department of Ultrasound, China-Japan Union Hospital of Jilin University. Changchun, Jilin 130-033, China; \\ ${ }^{3}$ College of Pharmacy, Jilin University, Changchun, Jilin 130-021, China.
}

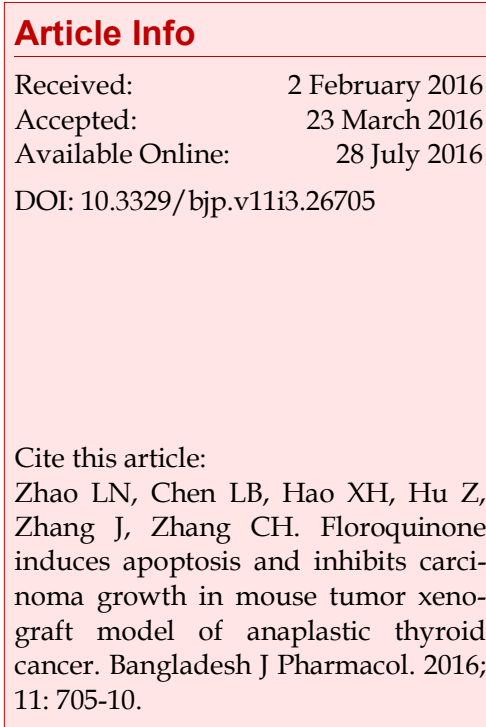

\begin{abstract}
In the present study, effects of floroquinone on anaplastic thyroid cancer cell lines and mouse tumor xenografts were investigated. Increase in the concentration of floroquinone from 10 to $100 \mu \mathrm{M}$ reduced the cell growth from 98 to $17 \%$ after 48 hours in HOTHC cells. Similarly, in FRO cells growth rate was found to be 96 and $21 \%$, respectively at 10 and $100 \mu \mathrm{M}$ concentrations of floroquinone. Western blot analysis showed a marked reduction in Bcl-2 expression and increased in Bax, caspase-3 and cleaved PARP expression in HOTHC cell lines on treatment with floroquinone. Floroquinone treatment of the HOTHC cells led to inhibition of the cobalt chloride-induced increase in the hypoxia-inducible factor $1 \mathrm{a}(\mathrm{HIF}-1 \mathrm{a})$ and vascular endothelial growth factor expression. In HOTHC cells, floroquinone treatment inhibited the tube formation and migration potential significantly compared to control cells. Treatment of the mouse bearing HOTHC tumor xenograft with 50 and $100 \mathrm{mg} / \mathrm{kg}$ doses of floroquinone alternatively for one month reduced the tumor volume to 48 and $17 \%$, respectively compared to the control. Thus, floroquinone effectively inhibits growth of thyroid cancer and can be used for its treatment.
\end{abstract}

\section{Introduction}

Thyroid cancer, malignant tumor of the endocrine gland, is commonly detected cancer in head and neck with behaviors ranging from occult differentiated to uniformly aggressive and lethal type (Sipos and Mazzaferri, 2010). Studies have revealed an increase in the rate of detection of thyroid cancer especially in radiologists who are frequently exposed to radiations and work stress (Enewold et al., 2009). Thyroid cancer rate has been estimated to be around $1.5 \%$ at present. Among thyroid cancers, anaplastic thyroid cancer (ATC) is the most lethal with median survival time of 6 months following diagnosis (Catalano et al., 2010; Fassnacht et al., 2009). At the time of diagnosis, ATC is in the well advanced stage and reached to a size of around $8 \mathrm{~cm}$. In the formation and progression of thyroid cancer gene- tic, environmental as well as several other factors are involved (Kim et al., 2003). For the treatment of differentiated thyroid cancers surgery and radioiodine therapy are used, however, undifferentiated thyroid cancers are resistant to drugs (Urciuoli et al., 2003; Pulcrano et al., 2007; Rajhbeharry singh et al., 2014; Nguyen et al., 2015). Therefore, the development of novel and efficient treatment therapies are highly needed for these tumors.

The characteristic features of cancer cells include, higher rate of proliferation, escape from apoptosis and markedly higher rate of replication, higher invasion and migration potential (Hanahan and Weinberg, 2011). The tendency of cells to escape the process of apoptosis makes them malignant bestows tumor forming ability (Johnstone et al., 2002). Induction of apoptosis in cancer 
cells by treatment with various chemotherapeutic agents is commonly used strategy for cancer treatment (O'Connor et al., 2000). The factors involved in the induction of apoptosis in cancer cells are caspases including caspase-3. Expression of the caspase-3 catalyzes the breakdown of components responsible for various cellular processes like DNA maintain and repairing (Riedl and Shi, 2004).

Natural products obtained from diverse sources play a vital role in arresting cancer cell growth by inducing apoptosis through increase in the expression level of caspases (Deep et al., 2010). Among the various classes of natural products, quinones possess promising anticancer activity and very low toxicity (Hua et al., 2006). The mechanism of action of quinones involve production of radical oxygen species, methylation of the biomolecules involved in vital cellular processes, chelation to DNA, etc (Wang et al., 2003). The present study was aimed to investigate the effect of floroquinone on the ATC in vivo and in vitro. It results demonstrated that floroquinone inhibited ATC cell viability through induction of apoptosis and inhibited angiogenesis.

\section{Materials and Methods}

\section{Cell lines and culture}

HOTHC and FRO ATC cell lines were purchased from the Shanghai Institute of Biochemistry and Cellular Biology Chinese Academy of Sciences (China). The cells were cultured in Dulbecco's modified Eagle's medium (DMEM; Gibco Life Technologies, USA) supplemented with $10 \%$ fetal bovine serum, $100 \mathrm{U} / \mathrm{mL}$ penicillin and $100 \mathrm{U} / \mathrm{mL}$ streptomycin in a humidified atmosphere of $5 \% \mathrm{CO}_{2}$ and $95 \%$ air at $37^{\circ} \mathrm{C}$.

\section{Animals}

Thirty C57BL/6 mice (age, 5 week old) were obtained from the Shanghai Laboratory Animal Center (China). The mice were housed in the animal facility center under specific pathogen-free conditions.

\section{MTT assay}

The growth of HOTHC and FRO ATC cell lines was analyzed using MTT assay. The cells were seeded at a density of $5 \times 10^{6}$ cells per well into the 96-well culture plate and incubated for 24 hours in an incubator with $5 \% \mathrm{CO}_{2}$ at $37^{\circ} \mathrm{C}$. Subsequently, the cells were treated with various concentrations of floroquinone and incubated for 48 hours. Following incubation, $20 \mu \mathrm{L}$ of MTT $(5 \mathrm{mg} / \mathrm{mL})$ solution was added to each well of the plate and incubation was continued for 4 hours more at $37^{\circ} \mathrm{C}$. The supernatant was decanted followed by the addition of $150 \mu \mathrm{L}$ dimethyl sulfoxide to each of the well. Absorbance for each of the well was measured three times at $490 \mathrm{~nm}$.

\section{Western blot analysis}

HOTHC and FRO ATC cell lines at a density of $2 \times 10^{6}$ cells per dish were plated in $6 \mathrm{~cm}$ dishes and cultured for 24 hours. The cells were then incubated with floroquinone for 48 hours, washed with PBS and subsequently lysed using mammalian tissue lysis/extraction reagent containing a protease inhibitor. The proteins were isolated using BCA protein assay kit and separated on $10 \%$ sodium dodecyl sulfate-polyacrylamide gel by electrophoresis. The proteins were transferred to nitrocellulose membranes and immune blotted with antibodies against caspase-3, cleaved caspase-3, Bcl-2, Bax and cleaved PARP for overnight. After incubation and washing with PBS the membranes were incubated with antirabbit or anti-mouse-conjugated alkaline phosphatase secondary antibodies for 1 hour at room temperature. The membranes were developed using an AP-Conjugated Development kit (Bio-Rad Laboratories). Quantification of the developed protein bands was performed using the Multi Guage V 2.2 program.

\section{DAPI staining}

HOTHC cells seeded onto the $18 \mathrm{~mm}$ cover glasses in DMEM medium were allowed to attain $\sim 70 \%$ confluence over a period of 24 hours. The cells were incubated with floroquinone for 48 hours, fixed in ice-cold paraformaldehyde, rinsed in PBS and subsequently stained with 4,6-diamidino-2-phenylindole (DAPI) for $30 \mathrm{~min}$ at $37^{\circ} \mathrm{C}$. A fluorescent microscope was used for the analysis of the nuclear fragmentation in DAPI-stained cells (Lin et al., 2015). TUNEL kit (Chemic on, USA) was used for performing TUNEL assay according to the manufacturer's instructions.

\section{Tube formation assay}

HUVEC tube formation assay was used for the analysis of tube forming tendency of HOTHC cells. Briefly, in conditioned medium obtained from HOTHC cells without treatment or after treatment with floroquinone, HUVEC cells were cultured using 96-well tissue culture plate which were coated with matrigel (BD Biosciences, USA) for a period of 24 hours at $37^{\circ} \mathrm{C}$ in an incubator with $5 \% \mathrm{CO}_{2}$ atmosphere.

\section{Migration assay (Video Clip)}

The wound-healing motility assay was used for the determination of HOTHC cell migration. The cells at a concentration of $2 \times 10^{5}$ were seeded onto 6-well plates treated with floroquinone and incubated for 48 hours. The cells were scratched using plastic cell scraper followed by PBS washing of the cell monolayer 3 times for removal of the detached cells. The cells adhered to the plates were incubated at $37^{\circ} \mathrm{C}$ in an incubator with humidified atmosphere of $5 \% \mathrm{CO}_{2}$. The reduction in width of the scraped zone of cells was used for the determination of cell migration. 


\section{Immunofluorescent staining}

After attaining confluence, HOTHC cells were seeded onto cover slips, exposed to $\mathrm{CoCl}_{2}$ for 1 hour and then treated with floroquinone for 48 hours. Following incubation, the cells were washed thrice in PBS and then fixed in 1:1 acetone/methanol for $10 \mathrm{~min}$. The cells were subsequently incubated with primary antibodies for overnight $(1: 100)$ at $4^{\circ} \mathrm{C}$, washed with PBS and finally incubated with FITC-conjugated secondary antibodies or with RITC-conjugated secondary antibodies (1:100) for 1 hour. The laser scanning confocal microscope was used for capturing the images.

\section{In vivo animal experiment}

The animals were subcutaneously inoculated into the dorsal area with $2.5 \times 10^{5}$ HOTHC cells per mouse. Following day 7 when the tumor diameter reached $>5$ $\mathrm{mm}$, the animals were divided into three groups, which included the control, high-dose floroquinone $(100 \mathrm{mg} /$ $\mathrm{kg}$ ) and low-dose floroquinone (50 mg/ $\mathrm{kg}$ ) groups. The animals in the low and high dose groups were administered intra-gastrically 50 and $100 \mathrm{mg} / \mathrm{kg}$, respectively doses of floroquinone. The animals in the control group received normal saline. On the day 30 following treatment, the animals were sacrificed by cervical dislocation to extract the tumor. The tumor weight was measured for the determination of inhibition of cancer growth.

\section{Statistical analysis}

All the data presented are the mean \pm SD. Statistical analysis of the data was carried out using ANOVA and Student's t-test. A statistically significant difference was considered at $\mathrm{p} \leq 0.05$. The SPSS software for Windows operating system (version 10.0; SPSS, USA) was used for the statistical calculations.

\section{Results}

\section{Growth of HOTHC and FRO cell lines}

The results from MTT assay showed a significant decrease in the growth of HOTHC and FRO ATC cell lines on treatment with floroquinone for 48 hours. The reduction in growth of HOTHC and FRO cell lines by floroquinone was found to be concentration dependent. Increase in the concentration of floroquinone from 10 to $100 \mu \mathrm{M}$ reduced the cell growth from 98 to $17 \%$ after 48 hours in HOTHC cells (Figure 1). Similarly, in FRO cells growth rate was found to be 96 and $21 \%$, respectively at 10 and $100 \mu \mathrm{M}$ concentrations of floroquinone.

\section{Apoptotic death in HOTHC cells}

Western blot analysis revealed a marked reduction in the expression of Bcl-2 in HOTHC cell line on treatment with floroquinone. The expression of Bax, caspase- 3 and cleaved PARP was increased on treatment of the cells with floroquinone for 48 hours (Figure 2A). Morphological examination of the floroquinone treated cells showed rounded shape and shrinking of the cell membrane. The results from DAPI staining revealed fragmentation of DNA and presence of perinuclear apoptotic bodies in floroquinone treated HOTHC cells (Figure 2B).

\section{Floroquinoneon angiogenesis}

HOTHC cells were exposed to $\mathrm{CoCl}_{2}$ which led to a significant $(p<0.005)$ increase in the expression of tumor angiogenic factors including, HIF-1 $\alpha$ and VEGF. The cells exposed to $\mathrm{CoCl}_{2}$ were incubated with floroquinone and the expression of HIF-1a and VEGF was examined. Floroquinone treatment of the HOTHC cells led to inhibition of the $\mathrm{CoCl}_{2}$-induced increase in the HIF-1a and VEGF expression (Figure 3). The inhibi-tion in the expression of $\mathrm{CoCl}_{2}$-induced HIF-1 was further confirmed by immunofluorescence using a confocal microscope.

Floroquinone treatment of HOTHC cells inhibited the tube formation potential significantly compared to control cells (Figure 4A). The migration potential of HOTHC cells was also inhibited on treatment with floroquinone (Figure 4B).

\section{Tumor growth in mouse xenograft model}

The effect of floroquinone on the nude mouse tumor xenograft was also analyzed. The results revealed a significant decrease in the tumor volume in floroquinone treated mouse compared to the control group (Figure 5A). Treatment of the mouse bearing HOTHC tumor xenograft with 50 and $100 \mathrm{mg} / \mathrm{kg}$ doses of floroquinone alternately for one month reduced the tumor volume to 48 and $17 \%$, respectively compared to the control animals. Similarly, the tumor weight in floroquinone treated mouse was decreased by 57 and $86 \%$ compared to control group by 50 and $100 \mathrm{mg} / \mathrm{kg}$, respectively doses of floroquinone treatment for one month (Figure 5B, $\mathrm{p}<0.05$ ).

\section{Discussion}

The compounds isolated from natural sources are investigated against various diseases either as single constituents or in the form of extracts (Yin et al., 1999). Quinones exhibit promising antitumor activity through different mechanisms which involve production of reactive oxygen species, DNA intercalation, alkylation of biomolecules, etc (Wang et al., 2003). The most important feature of quinones is that they act as potent anticancer agents with negligible toxicity (Hua et al., 2006). The present study demonstrates the effect of floroquinone on the growth of thyroid cancer cells both in vitro and in vivo. The current study demonstrated that floroquinone treatment of breast cancer cells significantly inhibited cell growth. The migration potential 


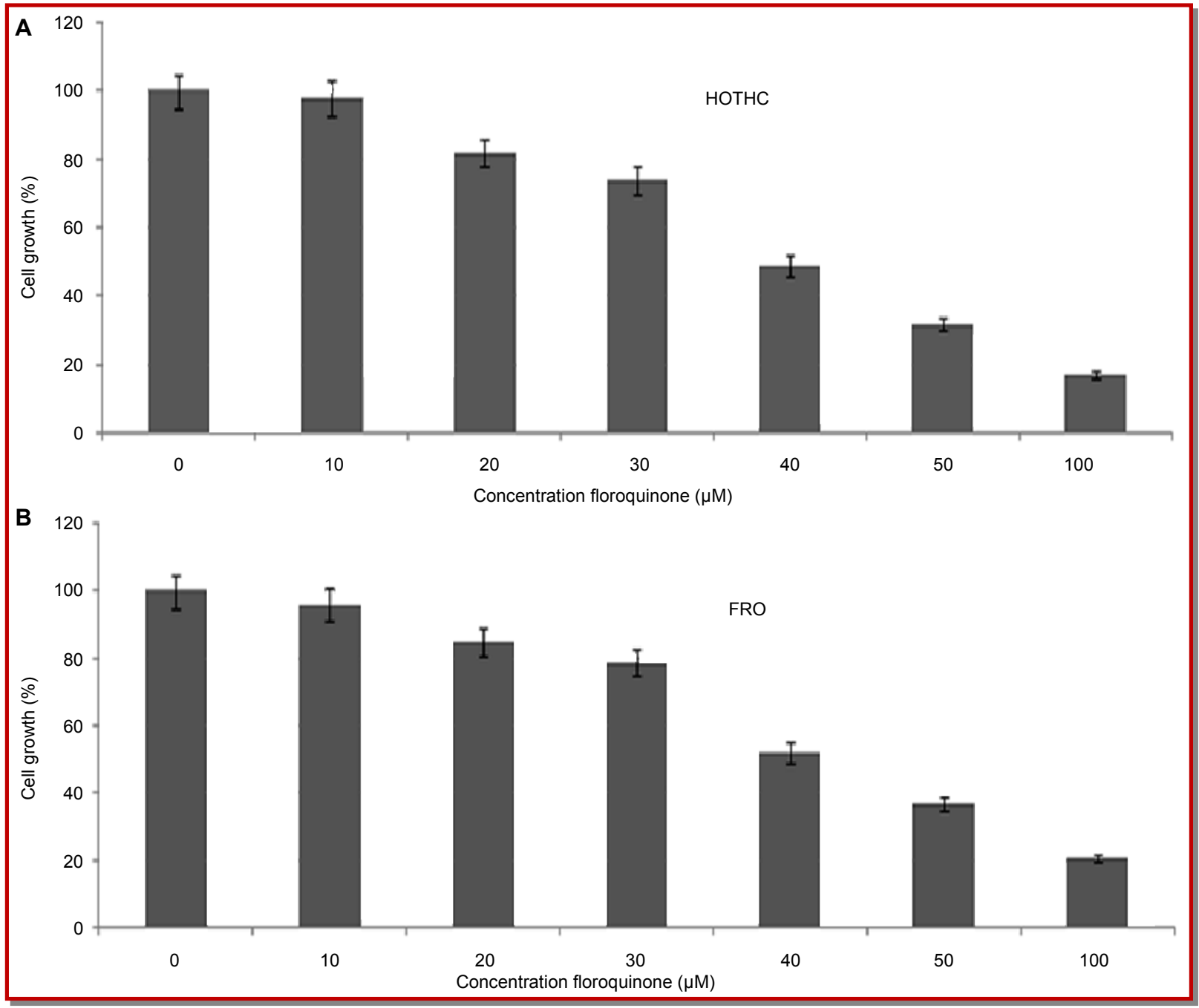

Figure 1: Floroquinone treatment for 48 hours inhibits growth of HOTHC and FRO ATC cell lines in concentration based manner. The cells were incubated for 48 hours with floroquinone followed by analysis using MTT assay. The data presented are the mean of three experiments performed independently

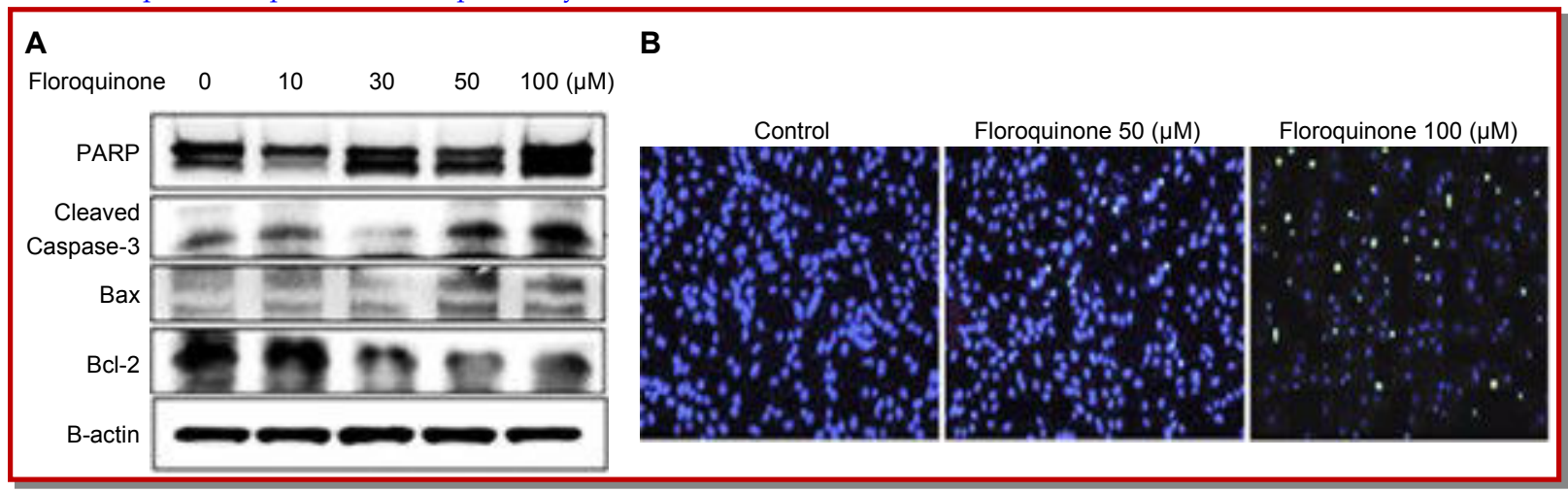

Figure 2: Floroquinone treatment of HOTHC cell lines induces apoptosis. (A) The cells were incubated with floroquinone for 48 hours and then analyzed by western blot assay for expression of apoptosis factors. (B) The cells after treatment with floroquinone were subjected to DAPI staining for analysis of apoptotic changes (magnification, x400)

of the breast cancer cells was inhibited on treatment with floroquinone. The inhibition of migration potential by floroquinone in breast cancer cells was associated with the suppression of HIF-1a and VEGF expression.
Induction of apoptosis in cancer cells by treatment with various chemotherapeutic agents is commonly used strategy for cancer treatment (O'Connor et al., 2000). The factors involved in the induction of apoptosis in 


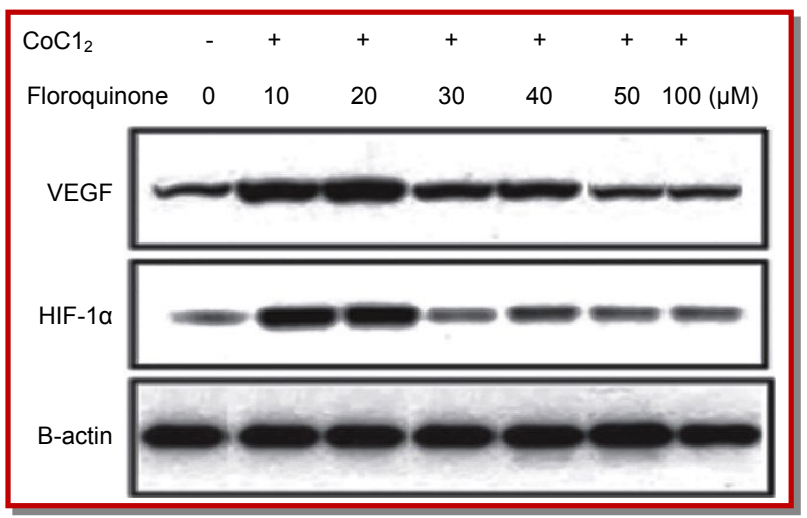

Figure 3: Floroquinone treatment of HOTHC cell lines inhibits angiogenesis. The cells after exposure to $\mathrm{CoCl}_{2}$ were incubated with floroquinone for 48 hours and then analyzed for HIF-1a and VEGF expression using Western blot assay and immunofluorescence

cancer cells caspases including, caspase-3. Expression of the caspase- 3 catalyzes the breakdown of components responsible for various cellular processes like DNA maintain and repairing (Riedl and Shi, 2004).
In the current study treatment of breast cancer cells with floroquinone increased the expression of caspase-3 and cleaved PARP. On the other hand, expression of $\mathrm{Bcl}$ -2 was decreased and that of Bax increased. Thus, floroquinone induces apoptosis in the breast cancer cells by increasing the expression of pro-apoptotic factors and decrease in the expression of anti-apoptotic factors. The cancer metastasis to other adjacent as well as distant organs and blood vessels is facilitated by the expression of VEGF (Folkman, 1990; Hanahan and Folkman, 1996). The expression of VEGF is controlled by other factors like, HIF-1a (Bolat et al., 2010). The current study demonstrated that floroquinone treatment of the breast cancer cells inhibited the expression of VEGF and HIF-1a.

\section{Conclusion}

Floroquinone exhibits promising inhibitory effect on the growth and metastasis of thyroid cancer cells. Thus floroquinone can be a potent molecule for the treatment of thyroid cancer.

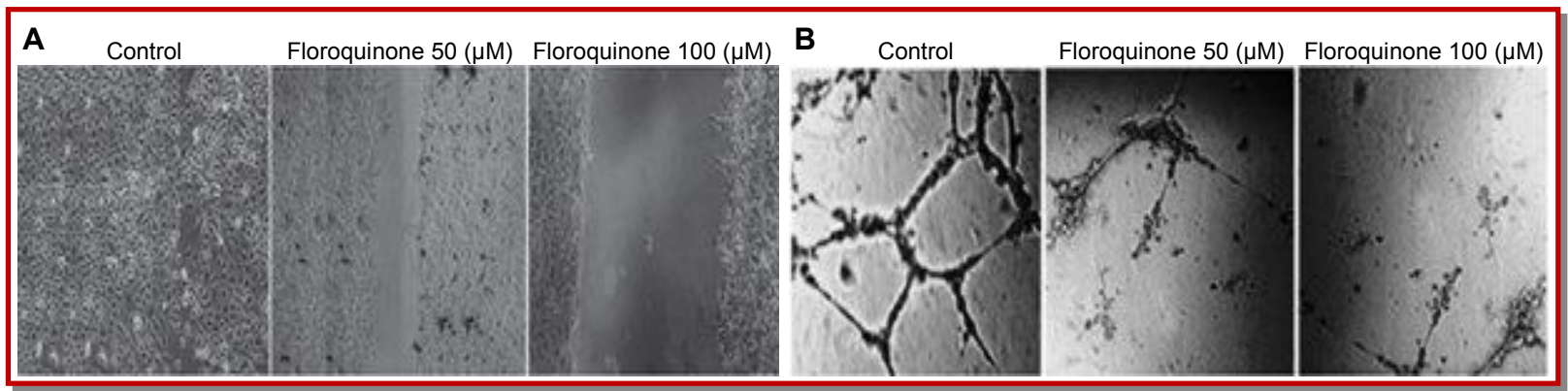

Figure 4: Floroquinone treatment of HUVECs cells inhibits angiogenesis. (A) The cells in matrigel were treated with floroquinone and then analyzed for tube formation potential. (B) The cells treated with floroquinone were analyzed for migration potential

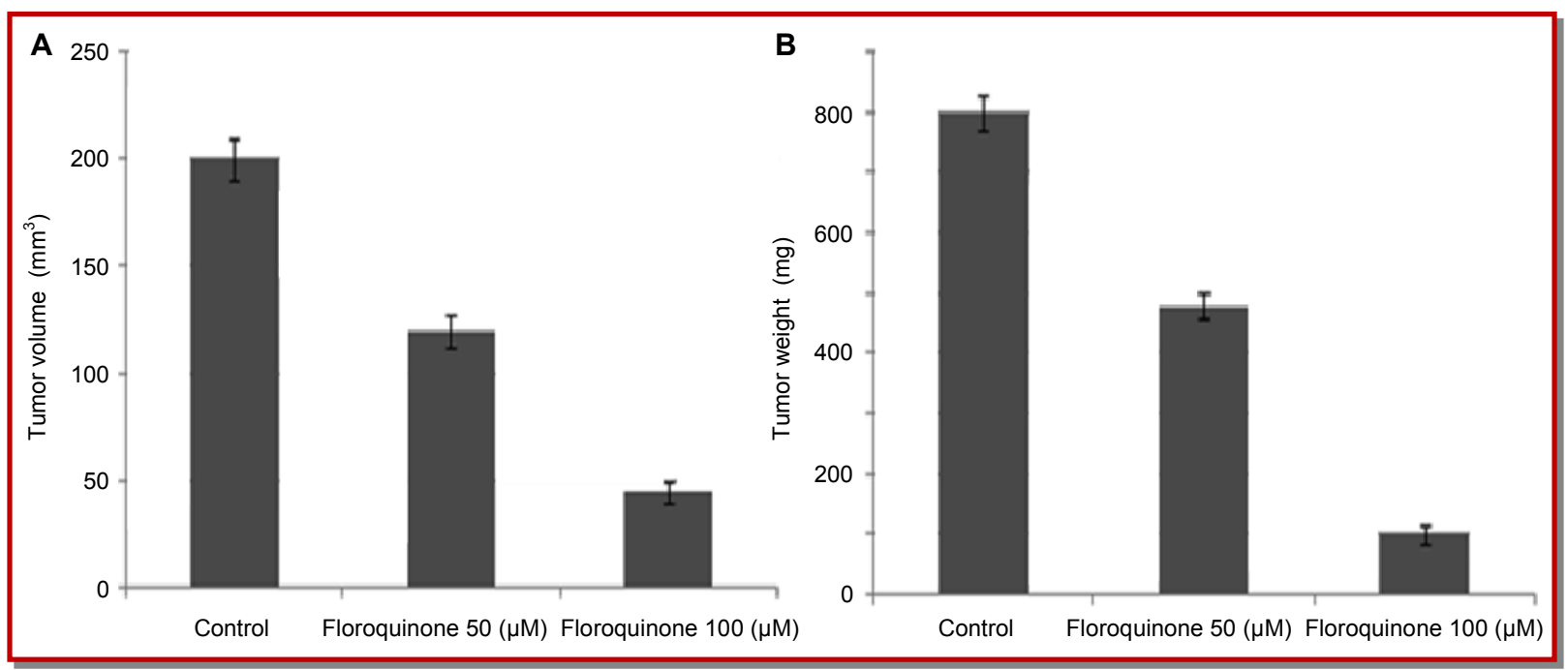

Figure 5: Floroquinone treatment inhibits tumor growth in vivo in the mouse xenograft model. HOTHC cells were administered in the mouse followed by treatment with 50 and $100 \mathrm{mg} / \mathrm{kg}$ doses of floroquinone for one month alternatively. After one month the mouse were sacrificed to extract the tumor for determination of (A) tumor volume and (B) tumor weight 


\section{Ethical Issue}

The animal treatment procedures were performed in accordance with the Principle of Laboratory Animal Care. All the experimental procedures approved by the Committee of Experimental Animal Administration of the Second Military Medical University Laboratory, Shanghai, China.

\section{References}

Bolat F, Haberal N, Tunali N, Aslan E, BalN, Tuncer I. Expression of vascular endothelial growth factor (VEGF), hypoxia inducible factor 1 alpha (HIF-1 alpha), and transforming growth factors beta 1 (TGF beta 1) and beta 3 (TGF beta 3) in gestational trophoblastic disease. Pathol Res Pract. 2010; 206: 19-23.

Catalano MG, Poli R, Pugliese M, Fortunati N, Boccuzzi G. Emerging molecular therapies of advanced thyroid cancer. Mol Aspects Med. 2010; 31: 215-22.

Deep G, Gangar SC, Oberlies NH, Kroll DJ, Agarwal R. Isosilybin $\mathrm{A}$ induces apoptosis in human prostate cancer cells via targeting Akt, NF-kappaB, and androgen receptor signaling. Mol Carcinog. 2010; 49: 902-12.

Enewold L, Zhu K, Ron E, Marrogi AJ, Stojadinovic A, Peoples GE, Devesa SS. Rising thyroid cancer incidence in the United States by demographic and tumor characteristics, 1980-2005. Cancer Epidemiol Biomarkers Prev. 2009; 18: 784-91.

Fassnacht M, Kreissl MC, Weismann D, Allolio B. New targets and therapeutic approaches for endocrine malignancies. Pharmacol Ther. 2009; 123: 117-41.

Folkman J. What is the evidence that tumors are angiogenesis dependent? J Natl Cancer Inst. 1990; 82: 4-6.

Hanahan D, Weinberg RA. Hallmarks of cancer: The next generation. Cell 2011; 144: 646-74.

Hanahan D, Folkman J. Patterns and emerging mechanisms of the angiogenic switch during tumorigenesis. Cell 1996; 86: 353-64.

Hua DH, Lou K, Battina SK, Zhao H, Perchellet EM, Wang Y, Perchellet JP. Syntheses, molecular targets and anti-tumor activities of novel triptycenebisquinones and 1,4-anthra- cenedione analogs. Anticancer Agents Med Chem. 2006; 6: 303-18.

Johnstone RW, Ruefli AA, Lowe SW. Apoptosis: A link between cancer genetics and chemo. Cell 2002; 108: 153-64.

Kim DS, McCabe CJ, Buchanan MA, Watkinson JC. Oncogenes in thyroid cancer. Clin Otolaryngol Allied Sci. 2003; 28: 38695.

Lin F, Peng Y, Yang Q, Mi X. Resveratrol inhibits cadmium induced neuronal apoptosis by modulating calcium signalling pathway via regulation of MAPK/mTOR network. Bangladesh J Pharmacol. 2015; 10: 366-76.

Nguyen QT, Lee EJ, Huang MG, Park YI, Khullar A, Plodkowski RA. Diagnosis and treatment of patients with thyroid cancer. Am Health Drug Benefits. 2015; 8: 30-40.

O'Connor L, Huang DC, O'Reilly LA, Strasser A. Apoptosis and cell division. Curr Opin Cell Biol. 2000; 12: 257-63.

Pulcrano M, Boukheris H, Talbot M, Caillou B, Dupuy C, Virion A, De Vathaire F, Schlumberger M. Poorly differentiated follicular thyroid carcinoma: Prognostic factors and relevance vb of histological classification. Thyroid 2007; 17: 639-46.

Rajhbeharry singh U, Taylor M, Milas M. Medical therapy for advanced forms of thyroid cancer. Surg Clin North Am. 2014; 94: 541-71.

Riedl SJ, Shi Y. Molecular mechanisms of caspase regulation during apoptosis. Nat Rev Mol Cell Biol. 2004; 5: 897-907.

Sipos JA, Mazzaferri EL. Thyroid cancer epidemiology and prognostic variables. Clin Oncol (R Coll Radiol). 2010; 22: 395-404.

Urciuoli P, Ghinassi S, Iavarone C, Peparini N, D'Orazi V, Gabatel R, Pichelli D, Iachetta RP, Custureri F. Thyroid anaplastic tumor: Our experience. Chir Ital. 2003; 55: 835-40.

Wang B, Perchellet EM, Wang Y, Tamura M, Hua DH, Perchellet JP. Antitumor triptycenebisquinones: A novel synthetic class of dual inhibitors of DNA topoisomerase I and II activities. Anticancer Drugs. 2003; 14: 503-14.

Yin F, Giuliano AE, Van Herle AJ. Growth inhibitory effects of flavonoids in human thyroid cancer cell lines. Thyroid 1999; 9: 369-76.

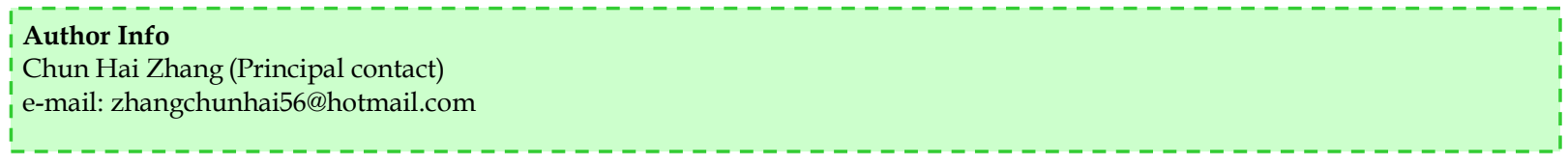




\section{Your feedback about this paper}

1. Number of times you have read this paper 0

2. Number of times you have seen the video clip 0

3. Quality of paper Click

4. Your comments

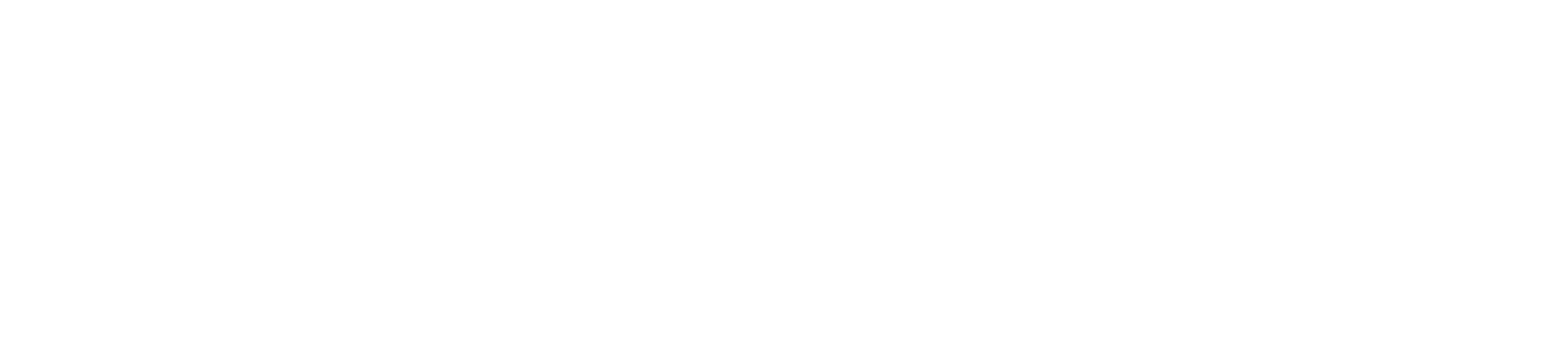

